\title{
PENERAPAN MODEL PEMBELAJARAN KOOPERATIF TIPE TEAM GAMES TOURNAMENT (TGT) DI KELAS X SMAN 4 KOTA BENGKULU
}

\author{
Application of Cooperative Learning Model Team Games \\ Tournament (TGT) Type In Class X SMAN 4 Bengkulu City
}

\author{
Safniyeti ${ }^{1}$, Abas $^{2}$, Aceng Ruyani ${ }^{3}$ \\ ${ }^{1}$ Program Studi Pendidikan Biologi, Fakultas Keguruan dan Ilmu Pendidikan, \\ Universitas Bengkulu, Provinsi Bengkulu, Indonesia. \\ 2,3 Staf Pengajar Program Studi Pendidikan Biologi, Fakultas Keguruan dan Ilmu \\ Pendidikan, Universitas Bengkulu, Provinsi Bengkulu, Indonesia. \\ email:ssafniyety@gmail.com
}

\begin{abstract}
Cooperative learning of Team Games Tournament (TGT) with numbered media card is one of teaching method that can be applied to biology. The objectives of this research were to describe the activities of teacher, activities of student student, and result student learning with apply cooperative learning model of Team Games Tournament (TGT). This was a classroom action research (CAR) with quantitative descriptive method and the subjects of this research were biology teachers and 34 students of SMAN 4 class XF Bengkulu city. The instrument used in this research was the observation and test sheets. Data collected were analyzed by calculating the average and specifies the range of values for each criterion, while the test of data analyzed calculating the average value of the class and percentage of completeness classical learning. Results of data analysis observation of the teacher activity first cycle obtained to score of 34.5 with good criteria, then increased in the second cycle to 38 with good criteria. The activity of students in the first cycle obtained score of 34.5 with good criteria, then increased in the second cycle to 37 with good criteria. The student learning results the first cycle of $73.55 \%$ with incomplete criteria then increased in the second cycle to be $88.23 \%$ with complete criteria. This applied model of learning type TGT could upgrade the activities of
\end{abstract}


teacher, activities of student, and the learning results of Biology students class $\mathrm{X}_{\mathrm{F}}$ SMAN 4 Bengkulu City.

Keywords: Cooperative Learning, Team Games Tournament (TGT); Result of learning, Student activity; Teacher activity

\section{PENDAHULUAN}

Pendidikan merupakan kebutuhan mutlak yang harus dipenuhi sepanjang hayat, tanpa pendidikan mustahil suatu kelompok manusia dapat hidup berkembang sejalan dengan citacita untuk maju, sejahtera dan bahagia menurut konsep pandangan hidup manusia. Semakin tinggi cita-cita manusia semakin menuntut kepada peningkatan mutu pendidikan sebagai sarana untuk mencapai cita-cita tersebut (Ihsan, 2003). Peningkatan mutu pendidikan dipengaruhi oleh keterampilan seorang guru dalam mengelola kelas (Kusumandari, 2011). Guru bertugas untuk membantu peserta didik mempelajari sesuatu yang belum diketahui, membentuk kompetensi, memahami materi yang dipelajari, dan mewujudkan tujuan hidup peserta didik (Kusumandari, 2011).

Penggunaan metode pembelajaran juga berperan penting dalam keberhasilan peningkatan mutu pendidikan. Metode mengajar akan berpengaruh terhadap kegiatan siswa selama proses belajar mengajar berlangsung. Metode mengajar yang digunakan harus disesuaikan dengan materi yang diajarkan dan kondisi siswa, sehingga siswa dapat terlibat secara aktif dan termotivasi untuk belajar serta tujuan pembelajaran dapat tercapai (Kusumandari, 2011).

Berdasarkan hasil observasi dan wawancara dengan guru biologi di kelas $\mathrm{X}_{\mathrm{F}}$ SMAN 4 Kota Bengkulu penulis memperoleh informasi bahwa kompetensi biologi siswanya yakni $80 \%$ dari keseluruhan siswa yang memperoleh nilai maksimal 75 maka barulah dikatakan tuntas. Guru telah menerapkan berbagai metode pembelajaran seperti diskusi, ceramah, dan kadang menggunakan charta untuk menunjang pembelajaran. Sumber belajar yang digunakan pada umumnya adalah buku dan lembar kerja siswa. Meskipun guru telah memaksimalkan pembelajaran dengan baik, 
tetapi masih ada siswa yang pasif dan kurang kreatif dalam mengembangkan materi pelajaran.

Kerjasama antar siswa untuk menuntaskan pemahaman terhadap materi pembelajaran sangat kurang, siswa lebih bersifat individual, dan hanya sebagian siswa yang memberikan kontribusi pada proses pembelajaran. Siswa yang mengerjakan tugas hanya yang memiliki minat dalam belajar sehingga tidak ada persaingan dalam pembelajaran. Hal tersebut berdampak buruk terhadap hasil belajar yang dibuktikan dengan hasil ulangan siswa dengan KKM 75. 34 orang siswa yang terdiri dari 19 orang perempuan dan 15 orang laki-laki hanya 10 orang yang tuntas pada materi pelajaran Protista dan persentase ketuntasan sebesar 29.41\%.

Berdasarkan permasalahan tersebut, Guru kelas $X_{F}$ SMAN 4 Kota Bengkulu sepakat dengan peneliti untuk melakukan perbaikan dengan menerapkan model pembelajaran kooperatif. Salah satu contoh model pembelajaran kooperatif adalah Team Games Tournament. (TGT). TGT merupakan salah satu jenis model pembelajaran kooperatif dimana setelah penyampaian materi dan pembelajaran kelompok akan diadakan tournament, siswa akan berkompetisi sebagai wakil dari kelompok mereka dengan anggota kelompok lain dengan kemampuan akademik yang sama. Model pembelajaran TGT ini melibatkan aktivitas seluruh siswa tanpa harus ada perbedaan status, melibatkan peran siswa sebagai tutor sebaya dan mengandung unsur permainan, siswa dapat belajar lebih rileks, menumbuhkan tanggung jawab, kepemimpinan, kejujuran, kerjasama, persaingan sehat, dan keterlibatan belajar (Nur, 2005). Menurut Prasetyaningrum, Martini \& Susilowati (2013), metode pembelajaran kooperatif tipe TGT dapat mengembangkan aktivitas dan kreativitas siswa untuk berpikir, berargumen, berbicara dan mengutarakan gagasannya serta diharapkan dapat meningkatkan aktivitas dan hasil belajar siswa.

Pembelajaran kooperatif tipe TGT terdiri dari 4 tahapan yaitu penyajian kelas (class precentation), belajar dalam kelompok (teams), permainan (games) atau pertandingan (tournament), dan penghargaan kelompok (team recognition) (Slavin, 2008). Pembelajaran TGT akan lebih mudah diterapkan apabila dikombinasikan dengan media pembelajaran pada saat turnamen. Media pembelajaran merupakan alat, metode, dan teknik yang 
digunakan untuk mengefektifkan komunikasi dan interaksi antara guru dan siswa dalam proses belajar dan mengajar di sekolah (Ahmad, 2003). Media pembelajaran yang dapat digunakan untuk permainan dalam pembelajaran TGT salah satunya adalah media kartu soal bernomor (Prasetyaningrum, Martini \& Susilowati, 2013).

Media kartu soal bernomor berisi soal-soal yang mencakup seluruh materi keanekaragaman hayati dan siswa harus menjawab soal tersebut dengan benar. Menurut Prasetyaningrum, Martini \& Susilowati (2013) media kartu soal bernomor digunakan dalam metode pembelajaran TGT karena mempunyai beberapa kelebihan yaitu mengubah kebiasaan belajar teacher centered menjadi student centered, mengefektifkan proses cooperative learning, menumbuhkan suasana kreatif dan enjoyfull learning, siswa terampil belajar mengerjakan soal sendiri, dan belajar mengatasi masalah.

Berdasarkan latar belakang tersebut, maka guru dan peneliti sepakat untuk memperbaiki proses pembelajaran di kelas $\mathrm{X}_{\mathrm{F}}$ SMAN 4 Kota Bengkulu dengan menerapkan model pembelajaran kooperatif tipe TGT pada materi keanekaragaman hayati. Penggunaan model pembelajaran TGT ini diharapkan siswa lebih memahami konsep pembelajaran biologi, meningkatkan kerjasama antar siswa, termotivasi untuk belajar, dan dapat meningkatkan hasil belajar karena bentuk evaluasi dalam pembelajaran ini berupa permainan akademik atau games yang cukup menyenangkan bagi siswa (Nur, 2005).

Hasil belajar siswa dapat dilihat dari hasil tes siswa dengan menggunakan posttest. Hasil belajar dinilai dari tingkat kognitif yakni pengetahuan (C1), pemahaman (C2) dan penerapan (C3). Tujuan dari penelitian ini adalah untuk mendeskripsikan aktifitas guru, aktifitas siswa, dan hasil belajar pada proses pembelajaran biologi dengan menerapkan Model Pembelajaran Kooperatif Tipe TGT di kelas $\mathrm{X}_{\mathrm{F}}$ SMAN 4 Kota Bengkulu. 


\section{Waktu dan Tempat Penelitian}

Penelitian ini dilaksanakan pada bulan Desember - Februari tahun ajaran 2012/2013 di SMAN 4 Kota Bengkulu.

\section{Jenis Penelitian}

Jenis penelitian yang digunakan adalah Penelitian Tindakan Kelas (PTK). Metode penelitian yang digunakan adalah metode deskriptif.

\section{Subjek Penelitian}

Subjek penelitian ini adalah guru yang terdiri dari 1 orang guru mengajar dan 2 orang guru yang bertindak sebagai observer dan siswa kelas $\mathrm{X}_{\mathrm{F}}$ SMAN 4 Kota Bengkulu tahun ajaran 2012/2013 yang terdiri dari 34 orang siswa.

\section{Variabel Penelitian}

Variabel bebas pada penelitian ini yaitu model pembelajaran kooperatif tipe TGT, sedangkan variabel terikat adalah hasil belajar biologi.

\section{Instrumen Penelitian}

\section{Lembar Tes}

Pada penelitian ini peneliti menyusun soal-soal berdasarkan indikator dan kisi-kisi soal. Jumlah soal sebanyak 7 soal per siklus. Adapun bentuk soal yang digunakan adalah essay, selain itu juga disertai dengan tes turnamen dalam bentuk soal pilihan ganda dan essay sebanyak 30 soal dengan media kartu bernomor.

\section{Lembar Observasi}

Lembar observasi yang digunakan adalah lembar observasi guru dan siswa. Lembar observasi guru meliputi 13 aspek pengamatan yang digunakan untuk mengamati guru dalam kegiatan belajar mengajar dengan menggunakan model pembelajaran kooperatif tipe TGT, sedangkan lembar observasi siswa meliputi 13 aspek pengamatan yang digunakan untuk melihat aktivitas siswa dalam mengikuti kegiatan belajar mengajar. Observasi ini dilakukan oleh dua orang observer. 


\section{Prosedur Penelitian}

Penelitian tindakan kelas ini dilaksanakan dalam dua siklus. Kurt Lewin dalam Aqib (2009) menyatakan bahwa dalam satu siklus terdiri dari 4 tahap yaitu: (1) Perencanaan (planning), (2) Pelaksanaan tindakan (action), (3) Observasi (observation), (4) Refleksi (reflection).

\section{Teknik Analisa Data}

\section{Lembar Observasi}

Menurut Sudjana (1989) analisis lembar observasi dapat dihitung dengan menggunakan rumus:

$$
\text { Rata }- \text { Rata Skor }=\frac{\text { Jumlah Skor }}{\text { Observer }}
$$

Skor tertinggi $=$ Jumlah aspek pengamatan $\mathrm{x}$ skor tertinggi

$$
\text { tiap kriteria }
$$

Skor terendah $=$ Jumlah aspek pengamat $\mathrm{x}$ skor terendah

$$
\text { tiap kriteria }
$$

Selisih skor $=$ Skor tertinggi - skor terendah

Kisaran nilai untuk tiap kriteria $=\frac{\text { Selisih Skor }}{\text { Jumlah Kriteria Penilaian }}$

\section{Hasil Belajar}

Tes yang diperoleh dianalisis dengan rata-rata nilai dan kriteria ketuntasan belajar, dimana proses mengajar dikatakan berhasil apabila 80\% siswa mendapatkan nilai 75.0 ke atas (berdasarkan KKM SMAN 4 Kota Bengkulu). Menurut Sudijono (2012) persentase ketuntasan belajar dapat dihitung dengan menggunakan rumus sebagai berikut:

$$
\mathrm{P}=\frac{F}{N} \times 100 \%
$$

Keterangan:

F $\quad$ : Frekuensi (jumlah siswa yang mendapat nilai $>75)$

$\mathrm{N} \quad$ : Jumlah frekuensi/banyak individu

$\mathrm{P} \quad$ : Angka persentase

Untuk nilai rata-rata siswa dihitung dengan rumus dalam Sudijono (2012) yaitu:

$$
\mathrm{M}=\frac{\sum X}{N}
$$


Keterangan:

M : Nilai rata-rata

$\sum \mathrm{X} \quad$ : Jumlah nilai peserta tes

$\mathrm{N} \quad$ : Jumlah peserta tes

\section{HASIL DAN PEMBAHASAN}

Penerapan model pembelajaran kooperatif tipe TGT pada pembelajaran biologi (materi Keanekaragaman Hayati) di kelas $\mathrm{X}_{\mathrm{F}}$ SMAN 4 Kota Bengkulu dapat meningkatkan aktivitas guru, aktivitas siswa dan hasil belajar siswa. Berdasarkan penelitian yang dilaksanakan sebanyak 2 siklus ini diperoleh hasil sebagai berikut:

Tabel 1.

Penerapan Model Pembelajaran Kooperatif Tipe TGT Pada Pembelajaran Biologi di Kelas $X_{F}$ SMAN 4 Kota Bengkulu

\begin{tabular}{|c|c|c|c|c|c|c|c|c|}
\hline Siklus & $\begin{array}{c}\text { Rata - } \\
\text { Rata } \\
\text { Skor } \\
\text { Aktivitas } \\
\text { Guru }\end{array}$ & $\begin{array}{c}\text { Rata - } \\
\text { Rata Skor } \\
\text { Aktivitas } \\
\text { Siswa }\end{array}$ & Kriteria & $\begin{array}{c}\text { Jumlah } \\
\text { siswa }\end{array}$ & $\begin{array}{c}\text { Jumlah } \\
\text { siswa } \\
\text { yang } \\
\text { mendapat } \\
\text { nilai } \geq 75\end{array}$ & $\begin{array}{c}\text { Nilai } \\
\text { rata- } \\
\text { rata } \\
\text { siswa }\end{array}$ & $\begin{array}{c}\text { Persen } \\
\text { tase } \\
\text { ketuntasan } \\
\text { belajar }\end{array}$ & Kriteria \\
\hline I & 34.5 & 34.5 & Baik & 34 & 25 & $\begin{array}{c}78.5 \\
5\end{array}$ & 73.52 & $\begin{array}{c}\text { Belum } \\
\text { tuntas }\end{array}$ \\
\hline II & 38 & 37 & Baik & 34 & 30 & $\begin{array}{c}90.7 \\
3\end{array}$ & 88.23 & Tuntas \\
\hline
\end{tabular}

Berdasarkan hasil observasi pada proses pembelajaran yang dilakukan oleh dua orang pengamat terhadap aktivitas guru selama kegiatan belajar mengajar, diperoleh rata-rata skor 34.5 pada siklus I dan meningkat menjadi 38 pada siklus II dengan kriteria baik. Rata-rata skor aktivitas siswa pada siklus I diperoleh sebesar 34.5 dan meningkat menjadi 37 pada siklus II dengan kriteria baik. Nilai rata-rata siswa pada siklus I sebesar 78.55 dan persentase ketuntasan belajar klasikal $73.52 \%$ dengan kriteria belum tuntas, namun pada siklus II meningkat menjadi $88.23 \%$ dengan kriteria tuntas. Proses pembelajaran dapat dikatakan baik apabila terjadi peningkatan terhadap aktivitas guru, aktivitas siswa, dan hasil belajar (Gambar 1). 

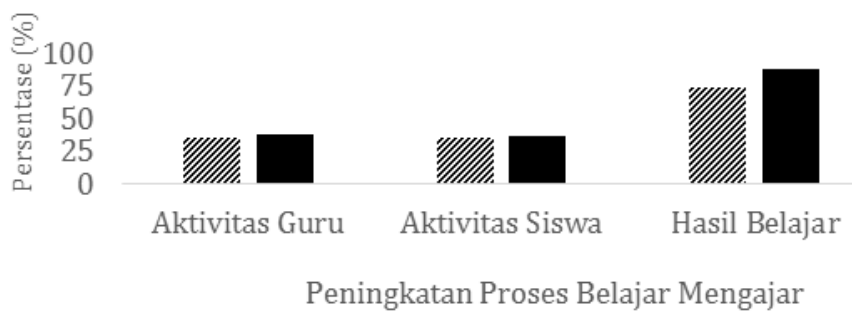

Gambar 1. Peningkatan terhadap aktivitas guru, aktivitas siswa, dan hasil belajar biologi siswa kelas $\mathrm{X}_{\mathrm{F}}$ SMAN 4 Kota Bengkulu dengan menerapkan model pembelajaran koopertif tipe TGT. 纞= Siklus I;

$\square=$ Siklus II

Gambar 1 menunjukkan adanya peningkatan aktivitas guru, aktivitas siswa, dan hasil belajar dari siklus I ke siklus II. Pada siklus I masih terdapat banyak aspek pengamatan aktivitas guru dan siswa yang belum bisa dilakukan dengan baik, namun pada siklus II aspek tersebut sudah diperbaiki. Peningkatan terhadap aspek pengamatan aktivitas guru dan siswa terjadi karena adanya perbaikan kelemahan yang terjadi pada siklus sebelumnya.

Berdasarkan aspek pengamatan aktivitas guru diketahui bahwa guru mengalami kesulitan dalam hal membimbing siswa pada saat melakukan diskusi. Guru sulit untuk membagi perhatiannya terhadap kelompok yang memerlukan bimbingan, hal ini disebabkan karena jumlah kelompok belajar dalam satu kelas berjumlah enam kelompok yang terdiri dari lima sampai enam orang siswa. Proses belajar mengajar menjadi kurang efektif karena jumlah kelompok terlalu banyak dan guru kesulitan membimbing siwa.

Guru juga mengalami kesulitan pada saat membimbing siswa melakukan turnamen. Kesulitan yang dialami guru disebabkan karena siswa belum terbiasa dengan model pembelajaran kooperatif tipe TGT dan siswa belum mengerti cara melakukan permainan, aturan untuk pembaca, penantang pertama dan penantang kedua, akibatnya waktu yang digunakan untuk permainan menjadi semakin lama. Hal ini sependapat dengan Prasetyaningrum, Martini \& Susilowati, (2013) bahwa pembelajaran yang disertai dengan adanya suatu permainan 
mempunyai beberapa kekurangan yaitu siswa akan bermain sendiri apabila tidak dipantau oleh guru dan memerlukan waktu yang lebih lama. Hamruni (2009) juga melaporkan bahwa kelemahan dari TGT adalah pada saat pembelajaran tim membutuhkan waktu yang relatif lama, sehingga siswa yang memiliki kemampuan lebih akan merasa terhambat oleh siswa lain yang memiliki kemampuan dibawahnya.

Pengamatan yang dilakukan pada aktivitas siswa diketahui bahwa siswa belum mampu menjawab dengan benar pertanyaan prasyarat yang diajukan oleh guru, siswa tidak mencatat informasi penting yang disampaikan oleh guru mengenai materi pokok yang dipelajari, siswa yang mampu menjawab pertanyaan yang ada pada LDS hanya 4 kelompok. Kelompok yang menang pada turnamen hanya memperoleh pengakuan tetapi tidak memperoleh penghargaan di akhir pelajaran. Hal ini disebabkan karena adanya jam darurat yaitu salah satu guru di sekolah tersebut mendapat musibah sehingga siswa pulang 30 menit lebih awal. Aspek pengamatan ini akan diperbaiki pada siklus II dengan memberikan penghargaan kepada kelompok yang memperoleh skor permainan tertinggi.

Kelemahan-kelemahan yang ditemukan pada aktivitas siswa dapat dikurangi dengan cara guru memberikan tugas kepada siswa pada minggu sebelumnya untuk membaca materi pelajaran berikutnya sehingga siswa telah mengetahui dasar-dasar materi yang akan mereka pelajari. Guru memusatkan perhatian siswa agar lebih menyimak informasi yang telah disampaikan, kemudian mengarahkan siswa untuk mencatat informasi tersebut dan akan menilai catatan siswa disetiap minggunya. Guru juga harus membimbing kelompok untuk saling bekerjasama dan membantu temannya yang kurang mengerti agar kelompok mereka dapat menjadi pemenang pada saat turnamen. Hal ini memotivasi siswa untuk aktif dalam pembelajaran di kelas dan tiap kelompok akan berlomba menjadi yang terbaik yang kemudian akan mendapat penghargaan (Prasetyaningrum, Martini \& Susilowati, 2013). Selain itu, guru harus menjelaskan aturan permainan secara jelas dan terstruktur dengan baik sehingga pada saat permainan berlangsung tidak ada lagi siswa yang bertanya mengenai aturan permainan tersebut. 
Peningkatan juga terjadi pada hasil belajar dari siklus I ke siklus II dan proses pembelajaran mencapai ketuntasan belajar klasikal pada siklus II. Berdasarkan analisa soal postest, pemahaman siswa terhadap materi pelajaran meningkat pada siklus II (Tabel 2). Persentase siswa yang menjawab benar pada soal tingkat kognitif C3 (penerapan) meningkat dari 50\% menjadi $81.6 \%$.

\section{Tabel 2.}

\section{Analisa Soal Postest Siklus I dan II dengan Metode Pembelajaran Kooperatif Tipe TGT pada Materi Keanekaragaman Hayati}

\begin{tabular}{|c|c|c|c|c|}
\hline \multirow{2}{*}{$\begin{array}{c}\text { No. } \\
\text { Soal }\end{array}$} & \multicolumn{2}{|c|}{ Siklus I } & \multicolumn{2}{c|}{ Siklus II } \\
\cline { 2 - 5 } & $\begin{array}{c}\text { Tingkat } \\
\text { Kognitif }\end{array}$ & $\begin{array}{c}\text { Rata- } \\
\text { rata }\end{array}$ & $\begin{array}{c}\text { Tingkat } \\
\text { Kognitif }\end{array}$ & $\begin{array}{c}\text { Rata- } \\
\text { rata }\end{array}$ \\
\hline 1 & C1 & 81.8 & C1 & 91.8 \\
\hline 2 & C2 & 83.3 & C2 & 100.0 \\
\hline 3 & C2 & 93.3 & C2 & 100.0 \\
\hline 4 & C3 & 50.0 & C1 & 81.8 \\
\hline 5 & C2 & 80.4 & C2 & 100.0 \\
\hline 6 & C1 & 100.0 & C1 & 100.0 \\
\hline 7 & C1 & 74.1 & C3 & 81.6 \\
\hline
\end{tabular}

Pada siklus I analisa soal postest menunjukkan bahwa dari 7 soal post test yang disusun oleh guru, soal no 6 merupakan soal yang paling banyak dijawab benar oleh siswa yakni sebesar 100\%. Soal no 6 ini merupakan soal tingkat kognitif C1 yaitu siswa diminta untuk menyebutkan pengertian dari istilah endemis. Soal yang paling banyak dijawab salah oleh siswa adalah soal no 4, siswa yang menjawab benar hanya $50 \%$. Soal no 4 ini merupakan soal tingkat kognitif C3 yaitu siswa diminta untuk menjelaskan mengapa pemanfaatan keanekaragaman hayati harus tetap terkendali. Kesulitan siswa dalam menjawab soal no 4 disebabkan karena tingkat kesukaran soal yaitu penerapan.

Analisa soal postest siklus II menunjukkan bahwa dari 7 soal post test yang dibuat oleh guru, soal no 2, 3, 5 dan 6 
merupakan soal yang 100\% dijawab benar oleh siswa. Soal-soal tersebut merupakan soal tingkat kognitif C1 yaitu tingkat pengetahuan. Soal yang paling banyak dijawab salah oleh siswa adalah soal no 7 , hanya $81.6 \%$ siswa yang menjawab benar. Soal no 7 ini, siswa diminta untuk membedakan pelestarian in-situ dan ex-situ serta memberikan contohnya. Kesulitan siswa pada saat menjawab soal no 7 ini disebabkan karena kurangnya perhatian siswa terhadap proses pembelajaran baik pada saat penyajian materi oleh guru maupun pada saat diskusi. Faktor lainnya yaitu tingkat kesukaran soal no 7 yakni tingkat kognitif C3. Namun secara keseluruhan pembelajaran dengan menerapkan model pembelajaran kooperatif tipe TGT pada pokok bahasan keanekaragaman hayati di kelas $\mathrm{X}_{\mathrm{F}}$ SMAN 4 Kota Bengkulu dapat meningkatkan ketuntasan belajar siswa.

Meningkatnya ketuntasan belajar siswa dengan menerapkan model pembelajaran kooperatif tipe TGT dikarenakan pada pembelajaran ini siswa lebih termotivasi untuk belajar, siswa bisa berdiskusi dan bekerja sama saling membantu teman sekelompoknya yang memiliki kemampuan akademik rendah, sehingga mereka secara bersama bisa menuntaskan bahan ajar yang mereka pelajari. Bentuk evaluasi pada pembelajaran ini berupa permainan akademik yang cukup menyenangkan. Hal ini sesuai dengan pendapat Nur (2005) yang menyatakan bahwa dengan menerapkan model pembelajaran kooperatif tipe TGT siswa lebih memahami konsep dalam pembelajaran biologi, lebih meningkatkan kerjasama antar siswa, lebih termotivasi untuk belajar, siswa lebih mengingat dan memahami apa yang telah dipelajari, siswa merasa belajar itu tidak membosankan karena bentuk evaluasi dalam pembelajaran ini berupa permainan akademik yang cukup menyenangkan bagi siswa. Berdasarkan angket secara berkelompok 61.36\% siswa menyenangi pembelajaran kooperatif tipe TGT (Sari \& Supardi, 2013).

Penerapan model pembelajaran kooperatif tipe TGT ini dapat meningkatkan aktivitas guru dan siswa. Peningkatan aktivitas tersebut berdampak positif terhadap peningkatan ketuntasan belajar siswa secara klasikal. Hal ini relevan dengan pendapat Kusumandari (2011) yang menyatakan bahwa 
penerapan model pembelajaran kooperatif tipe TGT dapat meningkatkan motivasi dan hasil belajar biologi. Pembelajaran kooperatif tipe TGT juga dapat meningkatkan prestasi belajar (Muldayanti, 2013; Sugiyo, Latifah \& Abidin, 2008), aktivitas belajar (Tyasning, Maryono \& Nurhayati, 2012), dan keaktifan siswa (Sani, Sudarmin \& Nurhayati, 2016). Selain matapelajaran IPA, TGT juga dapat diterapkan pada matapelajaran IPS seperti akuntansi (Susilowati, 2014). Pembelajaran kooperatif tipe TGT juga dapat divariasikan dengan pendekatan jelajah alam sekitar (Sugiyo, Latifah \& Abidin, 2008), LKS (Tyasning, Maryono \& Nurhayati, 2012), teka-teki silang (Fajri, Martini \& Saputro, 2012), roda impian (Prasetyaningrum, Martini \& Susilowati, 2013), dan media animasi (Desstya, Haryono \& Saputro, 2012).

\section{KESIMPULAN}

Perbaikan pembelajaran dengan menerapan model pembelajaran kooperatif tipe TGT selama proses pembelajaran biologi pada pokok bahasan keanekaragaman hayati dapat meningkatkan aktivitas guru, aktivitas siswa, dan hasil belajar dikelas $\mathrm{X}_{\mathrm{F}}$ SMAN 4 Kota Bengkulu. Aktivitas guru pada siklus I diperoleh rata-rata skor 34.5 dengan kriteria baik, kemudian meningkat pada siklus II menjadi 38 dengan kriteria baik. Aktivitas siswa pada siklus I diperoleh rata-rata skor 34.5 dengan kriteria baik, kemudian pada siklus II rata-rata skor meningkat menjadi 37 dengan kriteria baik. Peningkatan juga terjadi pada hasil belajar siswa kelas $\mathrm{X}_{\mathrm{F}}$ SMAN 4 Kota Bengkulu yaitu dengan persentase ketuntasan belajar siklus I sebesar $73.53 \%$ dengan kriteria belum tuntas dan pada siklus II sebesar $88.23 \%$ dengan kriteria tuntas.

\section{DAFTAR PUSTAKA}

Ahmad, S. (2003). Rancangan pembelajaran elaborasi. Malang: Bariklana 
Aqib, Z. (2009). Penelitian Tindakan Kelas. Bandung: Yrama Widya.

Desstya, A., Haryono, \& Saputro, S. (2012). Pembelajaran kimia dengan metode Teams Games Tournament (TGT) Menggunakan media animasi dan kartu ditinjau dari kemampuan memori dan gaya belajar siswa. Jurnal Inkuiri, 1(3), 177-182.

Fajri, L., Martini, K. S., \& Saputro, A. N. C. (2012). Upaya peningkatan proses dan hasil belajar kimia materi koloid melalui pembelajaran kooperatif tipe TGT (Teams Games Tournament) dilengkapi dengan teka-teki silang bagi siswa kelas XI IPA 4 SMA Negeri 2 Boyolali pada semester genap tahun ajaran 2011/2012. Jurnal Pendidikan Kimia, 1(1), 8996.

Hamruni. (2009). Strategi dan Model-model Pembelajaran Aktif dan Menyenangkan. Yogyakarta: Fakultas Tarbiyah Universitas Islam Negeri (UIN) Sunan Kalijaga.

Ihsan, H. F. (2003). Dasar-Dasar Kependidikan. Jakarta: Rineka Cipta.

Kunandar. (2011). Langkah Mudah Penelitian Tindakan Kelas Sebagai Pengembangan Profesi Guru. Jakarta: Raja Grafindo Persada.

Kusumandari, E. (2011). Penerapan Pembelajaran Kooperatif TGT (Team Games Tournament) Menggunakan Puzzle untuk Meningkatkan Motivasi Belajar Biologi Siswa Kelas VIIIe Smp Negeri 2 Ngadirojo Tahun Pelajaran 2010/2011. (Online), (http://biologi.fkip.uns.ac.id/wpcontent/uploads/2011/05/ 11.009-PENERAPAN-PEMBELAJARAN-KOOPERATIFTGT.pdf), diakses 17 Februari 2013. 
Muldayanti, N. D. (2013). Pembelajaran biologi model STAD dan TGT ditinjau ditinjau dari keingintahuan dan minat belajar siswa. Jurnal Penddikan IPA Indonesia, 2(1), 12-17.

Nur, M. (2005). Pembelajaran Kooperatif. Surabaya: Pusat Sains dan Matematika Sekolah UNESA.

Prasetyaningrum, D., Martini, K, S., \& Susilowati, E. (2013). Studi komparasi metode pembelajaran teams games tournament (TGT) disertai media kartu soal dan roda impian terhadap prestasi belajar siswa pada materi hidrokarbon kelas X SMA Negeri 7 Surakarta tahun pelajaran 2012/2013. Jurnal Pendidikan Kimia, 2(3), 122-129.

Sani, Z. M., Sudarmin, \& Nurhayati, S. (2016). Pembelajaran Team Game Tournament berbantuan media number card untuk meningkatkan keaktifan siswa. Jurnal Scientia Indonesia, 1(1), 56-65.

Sari, A. D. C., \& Supardi. K. I. (2013). Pengaruh model Team Games Tournament media Tournament Question Cards terhadap hasil belajar siswa pada materi hidrokarbon. Jurnal Inovasi Pendidikan Kimia, 7(2), 1220-1228.

Slavin, R. E. (2008). Cooperative Learning Teori, Riset dan Praktik. Terjemahan Nurulita Yusron. Bandung: Nusa Media.

Sudijono, A. (2012). Pengantar Statistik Pendidikan. Jakarta: PT Raja Grafindo Persada.

Sudjana, N. (1989). Penilaian hasil belajar mengajar. Bandung: PT. Remaja Rosdakarya.

Sugiyo, W., Latifah, \& Abidin, Z. (2008). Peningkatan hasil belajar siswa dengan model pembelajaran Team Game Tournament melalui pendekatan jelajah alam sekitar dan penilaian portofolio. Jurnal Inovasi Pendidikan Kimia, 2(1), 236-243. 
Sukardi. (2009). Metodologi Penelitian Pendidikan. Jakarta: Bumi Aksara.

Susilowati, D. (2014). Studi komparasi hasil belajar akuntansi dengan penerapan metode pembelajaran Teams Games Tournament (TGT) dengan metode ceramah bervariasi pada kompetensi dasar jurnal khusus siswa kelas XII IPS SMA Muhammadiya 01 Pati. Economic Education Analysis Journal, 2(3), 9-15.

Tyasning, D. M., Haryono, \& Nurhayati, N. D. (2012). Penerapan model pembelajaran TGT (Teams Games Tournament) dilengkapi LKS untuk meningkatkan aktivitas dan hasil belajar materi minyak bumi pada siswa kelas X-4 SMA Batik 1 Surakarta tahun ajaran 2011/2012. Jurnal Pendidikan Kimia, 1(1), 26-33. 